\title{
Professionalism as Symbolic Capital: Materials for a Bourdieusian Theory of Professionalism
}

\author{
Willem Schinkel ${ }^{\mathrm{a}}$ and Mirko Noordegraaf ${ }^{\mathrm{b}}$ \\ a) Associate Professor of Sociology, Erasmus University, PO Box 1738, \\ 3000 DR Rotterdam, The Netherlands \\ schinkel@fsw.eur.nl \\ b) Professor of Public Management, Utrecht School of Governance, Utrecht University, \\ Bijlhouwerstraat 6, 3511 ZC Utrecht, The Netherlands \\ m.noordegraaf@uu.nl
}

\begin{abstract}
Pierre Bourdieu has given a brief but fierce critique of the concept of "profession" that calls for a more reflexive analysis of the professions and in fact suggests not using the concept at all. In this contribution, we explicate the gist of that critique and argue it is possible to analyze it in a Bourdieusian fashion. We regard professionalism as a form of symbolic capital, the substance of which is constantly at stake in power-driven contexts, both internally and externally. Professional fields are embedded in objective relations with other fields in what Bourdieu describes as a general field of power. Within each professional field, the legitimate substance of what it means to act in a "professional way" is constantly at stake. In turn, across various professional fields, within what Bourdieu describes as a larger field of power, the very idea or "formal content" of "professionalism" is subject to struggle and (re)negotiation. This power-centered view emphasizes professionalism is a scarce symbolic resource, an object of a process of consecration and a source of legitimate forms of acting and interpreting. It thereby de-essentializes talk of professions and professionalization.
\end{abstract}

\section{Keywords}

fields of power, symbolic capital, professions, professionalism, professional capital, Pierre Bourdieu 
In sociology, the growth of professions and professionalism has been charted by many, starting in the first half of the twentieth century (cf. Carr-Saunders and Wilson 1933; Lewis and Maude 1952; for discussion, see Sciulli and Halley 2009). This was part of the sociology of work, which attuned itself to the increased role of the expert in modern society. Authors such as Talcott Parsons saw an increasing impact of professions on social structure (Parsons 1939). This kind of literature continued well into the 1960s (cf. Vollmer and Mills 1966; Faunce and Clelland 1967). Hence, in 1963, Bernard Barber spoke of the fact that we live in a "professional society" and a year later Wilensky critiqued the "sociological romance" of the "professionalisation of everyone." Since then, the sociological literature on professions has continued to expand (cf. Johnson 1972 and Macdonald 1995).

In this light, Pierre Bourdieu's vehement rejection of the concept of "profession" may seem surprising. It also leaves one to wonder whether or not a Bourdieusian approach to professionalism and to processes of professionalization is possible after all. We argue that it is. Professionalism can be seen as a form of symbolic capital in what Bourdieu (1994:55-56) terms the "field of power." In order thus to conceptualize professionalism, we first contrast existing approaches to Bourdieu's critique. And in order to fully grasp the import of this critique, we clarify the main methodological principles underpinning Bourdieu's work. We argue that adopting much of Bourdieu's relational approach allows for a workable, empirically useful conceptualization of professionalism as symbolic capital.

\section{Defining Professionalism}

Although it is impossible to define professionalism in crisp and clear terms, it is easy to identify the argumentative ammunition that is typically deployed when the notion of professionalism is used. The starting point for defining professionalism, whether this is done by lay people, by (professional) workers or by academic experts, is an emphasis on "good work" and the social mechanisms for accomplishing this. Professionalism refers to the occupational behaviours and practices of workers who not only have full-time jobs but also possess a clear sense of what their work is about and when it is effective. Some sort of collective - traditionally called a "profession" - guards and maintains this self-awareness. 
Medical doctors, for instance, fit this very basic definition: their medical acts are part of an occupation - medicine - which is organized and regulated by a collective - the medical profession. Such a profession secures the technical underpinnings of occupational practices (that is, knowledge and skills), defines successful practices and makes sure its members have a higher calling. Other classic examples are lawyers, engineers and university professors (e.g. Krause 1996). Other groups of workers that formed during the nineteenth and twentieth century are not seen so much as classic or "real" professions but nonetheless exhibit comparable features. Police officers, teachers and social workers, as examples, are part of recognizable occupational domains, with associations, education and supervision.

This basic understanding clarifies the mechanisms for becoming a professional. A professional does not merely work; he/she has to be educated and trained, (socialized) as member of an occupational domain, supervised by his/her peers and held accountable. Classic literature on professionalism has formalized this understanding to professionalism in more analytic terms. Professionalism, it is argued (e.g. Wilensky 1964; Freidson 1994, 2001), exists when workers are part of an occupational association that institutionalizes a technical base (knowledge and skills) as well as a service ethic (some sort of calling or higher purpose). This, in turn, calls for an autonomous space or jurisdiction that enables members of an association to control their own behaviours and practices.

Professionals succeed in realizing so-called "professional control:" they control themselves. Professionalism, in this sense, is a matter of internally organizing a profession and externally shielding-off professional practices from external influences. In cases of classic or 'pure' professions (cf. Noordegraaf 2007), this has happened to a high extent whereas other modern

professions such as policing or teaching are subjected to more internal fragmentation and external influences.

\section{Functional versus Power-Centred Approaches}

This basic understanding gets confused when it comes to explaining how professional control is established (for an overview, see Evetts 2003). According to functional accounts, internal control and external closure are important because professional workers have complex tasks and treat complex cases, for which they rely on esoteric knowledge. Because it is 
difficult to define and standardize their work in precise and measurable terms, and yet because their work is of great value to clients, it is important to initiate collective self-control by peers who experience the same complexities. To take a classic quote: "A profession may be defined as an occupation based upon specialized intellectual study and training, the purpose of which is to supply skilled service or advice to others for a definite fee or salary" (Carr-Saunders 1928).

This means that functional accounts have both micro and macro aspects. As far as micro aspects are concerned, authors rely upon functional definitions in order to stress the specifics of professional work. Professional workers, for example, have to make inferences when they treat cases; they must make translations between generic knowledge and the specific clients, dossiers or problems they have before them (e.g. Schön 1983). Because it takes time to master inferential skills, professional work must be protected from outside interference. At the same time, this might be said to legitimate professionals' special status.

As far as macro aspects are concerned, authors might show that professionals have distinctive positions in social life and society due to the significant work they perform (Carr-Saunders 1928; Parsons 1954). It is no wonder, then, that Evetts (2003) portrays these functional accounts of professionalism as "value systems" accounts.

These functional arguments have been heavily criticized. Critics argue that professionals have done a good job in shielding off their domain by: winning support from key players, such as the state or universities (e.g. Thorstendahl and Burrage 1990), generating "marketable services" (Larson 1977), and resisting attempts by other workers to form their own jurisdictions in an "ecology of professions" (Abbott 1988). Although the mechanisms might be the same (professionals still need associations, schooling, and the like), being a professional is no functional necessity. Rather, it is an outcome of a struggle over control, linked to more encompassing and changing occupational contexts (e.g. Leicht and Fennell 1997; Evetts 2003). Functional approaches are then replaced by powercentred approaches that highlight clashes between professions, as well as within professions, between professional 'segments' (see Bucher and Strauss 1961).

Power-centred approaches might be seen as modern anchors in the field of occupational sociology, applied to understand who controls work in 
post-industrial societies (Bell 1973). Such approaches might also be applied from more macro-sociological stances, in order to understand which groups control other groups in modern societies (cf. Johnson 1972). Evetts (2003) sees such accounts of professionalism as "ideology" accounts. It is quite common, for instance, to stress the status implications of professionalism as collective closure (Larson 1977), to explore the ideological effects of processes of inclusion and exclusion, and to criticize class distinctions that are produced or reinforced by professional groups or "castes." Why certain groups control others, or why some groups manage to gain status, often remains obscure, however.

This is where Bourdieu's work can be enlightening. Bourdieu's focus on and rejection of - professionalism does not merely match ideology-centred approaches; his work also enables us to explain how power is manifested, appropriated and exploited, and why shifts in power happen. A Bourdieusian understanding of professionalism strengthens our explanatory capacities.

\section{Bourdieu's Critique of Professionalism}

In order to provide a Bourdieusian understanding of professionalism, we first discuss Bourdieu's main objections to the notion of professionalism. We then relate these objections to some of the key features of Bourdieu's concept of social field. Consequently, on the basis of a critique of Bourdieu's dismissal of the notion of professionalism, we sketch the outlines of a notion of professionalism as symbolic capital. In this way we try to combine available accounts of professionalism and Bourdieusian thinking in order to get a fuller grasp of occupational dynamics.

Bourdieu's remarks on professionalism as a sociological concept are scarce and scattered. For one, this has to do with the relative absence of the use of the concept in France, where "occupation" is preferred. When he does critically discuss the concept, a critique of its particular national origin or its ethnocentric use is not far away (cf. Bourdieu 1998a; Bourdieu and Wacquant 1999). The gist of Bourdieu's substantive critique of the concept of profession is contained in his book with Loïc Wacquant, An Invitation to Reflexive Sociology (1992). Here the concept appears in a discussion concerning the role of language in the practice of reflexive sociology. 
Bourdieu calls into question notions such as occupational taxonomies for the reason that these are not sociological but bureaucratic categories. They are concepts "sociologists use without thinking about them too much because they are the social categories of understanding shared by a whole society" (Bourdieu and Wacquant 1992:241). Bourdieu then proposes to go one step further:

I believe that one must go further and call into question not only classifications of occupations (...) but the very concept of occupation itself, or of profession, which has provided the basis for a whole tradition of research and which, for some, stands as a kind of methodological motto. (Bourdieu and Wacquant 1992:242)

He then acknowledges the work done in the field of what we have called here the power-centered notion of professionalism, notably that of Larson (1977), Collins (1979), Friedson [sic] (1986) and Abbott (1988). But Bourdieu argues for the need to go beyond this work. For these purposes, he recommends using the concept of field as a replacement for the concept of profession. The main reason for this seems to be that, while amenable to a critical analysis of the conflicts inherent to the world of "professions," the very acceptance of the concept disallows a radically critical analysis. Bourdieu suggests that the use of the concept of "profession" implies taking on board a certain ideological background that hinders a truly critical sociological stance toward the object of sociological research. This is specifically the case because of the neutralizing and, what is more, naturalizing effects that the concept of profession has according to Bourdieu.

The reason the concept of profession is "dangerous," as Bourdieu says, lies in its "appearance of neutrality" (Bourdieu and Wacquant 1992:242). This does constitute an improvement on the "theoretical jumble" of Parsons, but the concept also deceives in that it adds weight to a fictive reality. That is, it binds together various people under the same name, having a similar economic status and organized in a similar way. Bourdieu therefore concludes:

"Profession" is a folk concept which has been uncritically smuggled into scientific language and which imports into it a whole social unconscious. It is the social product of a historical work of construction of a group and of a representation of groups that has surreptitiously slipped into the science of this group. (Bourdieu and Wacquant 1992:242-243) 
This is precisely why, according to Bourdieu, the concept "works so well." In fact, it works "too well."

Accepting a certain received notion of "profession" leads one to find directories, library entries, lists, biographies, etc., which helps to add credibility to the concept. It thereby becomes what Emile Durkheim, speaking of religion, called a "well founded delirium" (Durkheim 1915). A delirium, but well founded nonetheless, since it is reified from various sides throughout social life.

In another context, Bourdieu himself similarly discusses the idea of the artist as the sole creator of a work of art as a "well founded illusion" (Bourdieu 1993). Such illusions are well founded for one because they involve the collaborative effort of various individuals sharing a similar set of dispositions or habitus. These individuals rely on a social field to give collective credibility to a work of social construction.

But in the case of the concept of "profession" in social science, the work of construction is done, according to Bourdieu, by the wrong crowd. It is the task of the sociologist to construct a group as a unit of sociological analysis. In such a construction, the sociologist must of course be attentive to the work of construction, that is, of "aggregation and symbolic imposition" (Bourdieu and Wacquant 1992:243) carried out by social actors themselves. But the sociologist, in Bourdieu's framework of sociology, can never forego his or her own work of construction by readily accepting, without critical scrutiny, the constructions by these actors themselves as the definitive framework of the social reality under study.

It is in this sense that Bourdieu has been criticized on the grounds of "knowing more than the actors themselves" (Latour 1996:199). But what exactly is the ideological import Bourdieu assumes the notion of profession necessarily entails? For one, the notion is too functionalist to Bourdieu's taste, as it is a "bureaucratic concept." This means it veils the "space of competition and struggle" (Bourdieu and Wacquant 1992:243) that lies underneath ordinary usage of the term. In the most general sense, Bourdieu's problem with the concept is that it universalizes what is particular (compare to Bourdieu 2000b:274). The task of sociology is not to cooperate in such universalization but rather to unveil it.

Nonetheless, beyond this lies the critical task of the sociologist to "universalize access to the universal" (Bourdieu 1998b). Bourdieu's critique of professionalism in fact has all of the characteristics of a critique in the Kantian sense: it is a critique of professionalism in that it scrutinizes the 
(social) conditions of possibility of the concept of profession. It for instance enables the observation that the early theorists of professionalism, which worked in the post-Depression era, favoured the "liberal professions" over against working-class occupations as a model of professionalism (Carr-Saunders and Wilson 1933). Although he hardly gave such examples, such power-laden particularisms are good examples of what Bourdieu warns against.

In order to understand the background of Bourdieu's critique of the concept of profession as well as the contours of his alternative approach, it is helpful first to elaborate briefly on basic principles underlying Bourdieu's work in general. In the next paragraph, we therefore discuss Bourdieu's methodological attitude best characterized by the "relational logic" underpinning his analysis. Then, we move to the concepts of illusion and doxa in order to illuminate the Bourdieusian way of looking at concepts in social fields. This enables us to move on to the field of social science, and its Bourdieusian prerequisite of reflexivity - which became apparent in his critique discussed above. The last two paragraphs then contain a critique of Bourdieu's critique and an attempt to salvage, in a Bourdieusian way, the concept of "profession" from Bourdieu's rather derogatory treatment.

\section{The Methodological Background}

Bourdieu's chief concern has been to mediate between various oppositions that, he perceived, tears the social sciences apart theoretically. In navigating between subjectivism and objectivism, or between formalism and structuralism, his concept of habitus is crucial, and we comment on its role in the context of professionalism below. Bourdieu, however, was a student of Lévi-Strauss and profoundly influenced by structuralism. Although he later departed from a structuralist formal analysis in terms of binary oppositions, which still very much characterize his early work on Algeria (although even there Bourdieu was never simply a structuralist), his work has been based on a methodological principle that has strong structuralist origins.

The relational logic that made possible Bourdieu's "genetic structuralism" or his "relational" mode of thought and analysis finds its origins in 
what is often regarded as the "father of structuralism," the Swiss linguist Ferdinand de Saussure. Although Bourdieu's emphasis on relational analysis stems from various sources, including Bachelard and Cassirer (see Vandenberghe 1999; Robbins 2000), what Bourdieu takes from Saussure is the crucial ingredient in his relational logic.

Saussure's famous analysis, in his Course in General Linguistics (1916), of the relation between signifier (signifiant) and signified (signifié) plays a pivotal role here. This relation is conceived by Saussure as arbitrary. It is regulated by a code which does not rest on any intrinsic connection between signifier and signified. Thus, language, as a system (langue) opposed to the practice of speech (parole), consists of a regulated set of differences in which each sign gains meaning first of all by virtue of a "negativity," that is, through its difference vis-à-vis all other signs within the system. Therefore, Saussure states "in language, there are only differences" (1916:118).

Applying this to subjects other than langue was what various structuralist authors did. Lévi-Strauss, for example, based on what Saussure had called the "principle of difference" and the "principle of arbitrariness" applied Saussurean relational thinking to culture in general or to kinship systems. He treated these as analogous (though not uncritically) to the way Saussure treated langue or the system of language (Lévi-Strauss 1963). As Bourdieu puts it in Raisons Pratiques: "Le réel est relationnel" (Bourdieu 1994:17; compare Bourdieu 1992:97).

Bourdieu does not set out to recapitulate either Saussurean or LéviStraussian systems. Rather, he takes issue with Saussure's distinction between langue and parole because the performance of speech is a process of distinction and is as such characterized by power (Bourdieu 2001a). But he does retain the idea that (social) differences are in the end arbitrary in nature, and thus meaningful only through the fact that they differ and the fact that a work of social construction exists to imbue these differences with meaning according to a dominant form of what Max Weber called "legitimate order."

This idea is applied by Bourdieu in his analysis of various social fields, such as those of cultural production (1993), science (1982, 1984, 1997b, 2001b), education (1996b), journalism (1998), politics (2000a) and the economy (2000b). But it is perhaps best illustrated by his analysis of the "social space of classes" in La distinction (1996a). What Bourdieu's 
analysis adds here, among other things, to earlier comparable work by Veblen and Simmel is his meticulous empirical analysis of the preferences of taste. He is able to cluster these preferences into three classes (allowing for various class factions) and to interpret them as having no intrinsic meaning of value. They are initially arbitrary differences that are socially consecrated as "distinctions" (Bourdieu 1996a). He thus analyses the space of the classes as comprised of socially produced differences, that is, as differences that only become socially relevant differences - distinctions after their adjustment to, among other things, a legitimate linguistic disposition, a legitimate aesthetic disposition, and so forth.

Through such dispositions, the fluent acquirement and hence in a sense "invisible" functioning of which is restricted to the higher class, power becomes productive in the coding of preferences. In symbolic struggles the arbitrary is not recognized as such (Bourdieu 2001:207). Distinction is then at the same time (social) distance. But the differences through which distinctions are constructed function, for Bourdieu, as Saussurean differences in a relational system. This means that objects of taste gain meaning and substance only by virtue of their socially produced relation to other objects of taste.

Directly of relevance to our discussion of the concept of "profession" and "professionalism," Bourdieu states in La distinction:

What is at stake in the struggles about the meaning of the social world is power over the classificatory schemes and systems which are the basis of the representations of the groups and therefore of their mobilization and demobilization: the evocative power of an utterance which puts things in a different light (...) shows something else (...); a separative power, a distinction, diacrisis, discretio, drawing discrete units out of indivisible continuity, difference out of the undifferentiated. (Bourdieu 1996a:479)

Social life thus consists of struggles over legitimate forms of classification. These legitimate classifications are imbued with the power to produce differences, or distinctions, which are arbitrary - to the extent that prior to the work of social construction based on dominant classificatory schemes there were no socially relevant differences.

In Raisons Pratiques Bourdieu explains further the title of his main work in relational terms: 
The very title Distinction serves as a reminder that what is commonly called distinction, that is, a certain quality of bearing and manners, most often considered innate (one speaks of distinction naturelle, "natural refinement"), is nothing other than difference, a gap, a distinctive feature, in short, a relational property existing only in and through its relation with other properties. (Bourdieu 1994a:20)

This illustrates the Saussurean influence on Bourdieu's work. Bourdieu analyses the historical genesis of social fields in which the social production of difference (faire des différences) is at stake (Bourdieu 1994:152). Perhaps most succinctly put Bourdieu states to this end:

I think that the core of my thought is that the properties attached to different individuals, constitutive of a society, constitute an system (ensemble) of differences which, when they are perceived by agents gifted with the necessary discernment (...), function like the elements of a system of differences, or of distinction, which is totally structurally comparable to a system of phonemes - the material properties attached to an individual and to the individual's properties function like distinctive signs. (Bourdieu 2000, personal communication; also in Schinkel and Tacq 2004)

This methodological background is indispensible for a proper understanding of the fundamental nature of Bourdieu's critique of the concept of profession. Although he never spent an entire paper let alone a book on the subject, his scattered - derogatory - remarks have to be seen in light of his relational analysis. This means the notion of profession surfaces as a socially consecrated and legitimated concept within a field of differences. Given this, Bourdieu sees the concept as instilled with the power to make a distinction, that is, to assert dominance. In order to explain how Bourdieu conceptualizes such power processes, we now turn to a brief discussion of the notions of doxa and illusio in what Bourdieu terms social fields.

\section{The Status of Concepts in Social Fields: On Doxa and Illusio}

As we have seen, Bourdieu proposes not to conduct analyses in terms of profession, professionalism and professionalization but rather in terms of autonomous, historically constituted social fields. Bourdieu understands a field as a system of positions. Whereas a habitus is seen by Bourdieu as an 
acquired system of dispositions (Bourdieu 1977:72), a field is the social space of the corresponding positions, a network of the relations between such positions (Bourdieu 1984:113; 1992:97). A basic principle of any social field is "the arbitrary" (Bourdieu 1997a:116). A social field is always a field of force, of power, and it is through power that the arbitrary is naturalized. What it at stake in a field are various forms of capital.

Bourdieu roughly discerns economic, social and cultural capital (1986, 1996a). On top of this, he discusses symbolic capital - as any of these three forms of capital yet unrecognized as such (1993:75). Symbolic capital can be cultural capital but in a way this recognizes it as a token of status, which is not the case in any odd social field. It is thus a form of capital that is in a sense "transubstantiated" and recognized as the legitimate token of status. In the field of education (1984) or that of (restricted) cultural production (1993) cultural capital is symbolic capital; in the field of the economy, it is not.

So what is at stake in any social field is, in the end, symbolic capital. But this also means that the dispositions which allow individuals their sens pratique or their sens $d u$ jeu are constantly at stake. The legitimate definitions of acting and interpreting in a social field are themselves the stakes (enjeu) of such a field.

What is ultimately at stake in a social field is designated by Bourdieu as doxa. Doxa prescribes the presuppositions of a field (Bourdieu 1990a:66); it is its doxa that properly defines a field (Bourdieu 1997a:22). Any field entails a lived experience that is "quasi-bodily." A field's doxa provides this taken-for-grantedness of a shared common sense world (Bourdieu 1990a:68). This is possible because the habitus is "an acquired system of generative schemes objectively adjusted to the particular conditions in which it is constituted" (Bourdieu 1977:95). The better adjusted one's habitus is to the field in which one occupies a position, the better one's "sense of the game" and hence one's ability to acquire symbolic capital and a dominant position in this specific field.

In addition, a social field is also invested with a certain illusio, that is to say, with a beliefin the merits of what is at stake in a field (croyance fondamentale dans l'intérêt du jeu et les valeurs des enjeux) (Bourdieu 1997a:22). As Bourdieu explains, on the basis of Huizinga's etymological association between "illusion" and "ludus" (game), illusio has reference to a "taking 
the game seriously," to a belief that a social game is important (Bourdieu 1994:151; compare 2000b:21).

Both doxa and illusion grant credibility to the functioning of a social field. They foster belief in the basic categories of this field, which at the same time means they foster belief in the need for struggle over these basic categories. This means that those who occupy lesser positions in a field subscribe to the legitimacy of the principles according to which their position is allotted to them. Here Bourdieu speaks of symbolic violence as a violence that entails forms of submission that are not recognized as such (Bourdieu 1994:188; 1999:126). In other words: it is a violence taking place with the consent of the violated (Bourdieu 1997a:204).

In the end, this is what belief in the stakes of a social field entails for Bourdieu. Fields are always social spaces of struggle, just like the social space of the classes. They are spaces of struggle over forms of capital deemed legitimate or, in other words, over symbolic capital as a field-specific form of status. Such forms of capital are in the end based on properties bereft of intrinsic social value. They gain their meaning through a relational play of differences; social space is in the end a space of differences (Bourdieu 1994:28).

\section{A Reflexive Social Science of the Professions}

\section{The Concept of Profession in Sociology: Baby or Bathwater?}

The very idea of a profession evidences what Bourdieu describes as illusio. The professions involve the idea of a profession. A professional is one who professes to fulfil a certain moral task, similar to the way the German word for "calling" is Beruf, which also means 'occupation' (as for instance in Max Weber's Der Beruf zur Politik). The methodological background of Bourdieu's work helps to explain his critique of the concept of profession. This concept is part of a struggle for symbolic capital.

Bourdieu's repeated calls for a "reflexive sociology" entail that the relational character of social life is recognized by the social scientist. This social scientist therefore can never use the concepts prevalent in social life because such concepts are the consequence of a social process of consecration. They are possible only on the basis of various "institutional rites:" 
Parler de rite d'institution, c'est indiquer que tout rite tend à consacrer ou à légitimer, c'est-à-dire à faire méconnaître en tant qu'arbitraire et reconnaître en tant que légitime, naturelle, une limite arbitaire. (Bourdieu 2001a:176) ${ }^{1}$

This goes for the concept of profession, which is therefore not to be taken at face value. Social science is, as Bourdieu states, "a social construction of a social construction” (Bourdieu 2001b:172). Its reflexivity means gaining the possibility to check those factors that bias research (Bourdieu 2001:174). Bourdieu's main critique of the concept of profession, in short, comes down to the idea that its use involves an uncritical acceptance of a concept laden with distinctive profit and symbolic value particular to a specific social space.

Similar to the way Michel Foucault analyzed various professions as "disciplines," in the double sense of the word, Bourdieu emphasizes the particularity of power struggles in the realm of the "professions." He thereby stresses the need for social science to distance itself from the concept. Social scientific ratification of the concept of profession, can, in Bourdieu's view, only contribute to the field-specific legitimacy of an in the end arbitrary social construction. Reflexivity in social science means taking this danger into account.

"Profession," by this reasoning, is a manifestation of the arbitrary in the guise of the natural. It is a concept of domination, which, for instance, becomes apparent in the distinction between "professions" and "semi-professions" (cf. Etzioni 1969) and also in the declassification of working class occupations in relation to the classification of liberal professions (cf. Carr-Saunders and Wilson 1933).

However, we argue that it is possible not to throw the baby out with the bathwater: to retain the concept of profession in some form while maintaining critical distance from the "native" point of view. In other words, it is possible to accept the Bourdieusian critique of a concept that functions as an element of illusio in occupational fields. But, we argue, it is also possible to regard professions as occupational fields in Bourdieu's sense, and as themselves enmeshed in a larger field of struggle between such professional and extra-professional or newly professionalizing fields.

1) "To speak of an 'institutional rite' is to indicate that every rite gives rise to consecration or legitimation, that is to say to misjudge as arbitrary and to recognize as legitimate and natural an arbitrary limit." 
Moreover, we believe it is imperative, precisely because of the powerdriven functioning of the concept of profession, to retain this concept as an analytical tool. But we propose to retain it firmly embedded in a framework inspired by Bourdieu, namely as a highly specific form of symbolic capital.

\section{A Critique of Bourdieu's Critique}

It is precisely in light of his calls for reflexivity that one can critique Bourdieu's critique of the concept of profession. Bourdieu's focus in his explicit critique of the concept of profession is characterized by a particular kind of "methodological nationalism" (Smith 1983). While justly emphasizing the problems in translating concepts such as "minority" or "profession" (Bourdieu and Wacquant 1999) and hence the need to take care not "to universalize a particular," he never made a comparative analysis of phenomena crossing the Atlantic divide (apart from, perhaps, his later incursions in the realm of critique of "neo-liberalism;" see Schinkel 2003).

The "worldwide export of US scholarly categories" (Bourdieu and Wacquant 1999:48) is not a proper object of research in Bourdieu. Nor, for instance, are social processes indicative of global convergence, which various authors have emphasized as existing alongside local divergence (cf. Robertson 1995). In a related fashion, Bourdieu critiqued fashionable concepts that were put to all-too-universalizing uses: "The word 'globalization' is ... a pseudo-concept that is at once descriptive and prescriptive that has taken the place of the word 'modernization,' which has long been used by the American social sciences as a euphemism in order to impose a naïve ethnocentric evolutionary model, that allows different societies to be classified by their distance from American society..." (2001a:96-7, our translation; compare Bourdieu 2000b:277). Yet studies of what is known under the umbrella concept of "globalization" have meanwhile added much nuance to what is analyzed under such admittedly fashionable headings.

What is more, it remains to be seen how legitimate Bourdieu's dismissal of various ideological concepts is when the scope of his own work is taken into consideration. In fact, Loïc Wacquant's assertion that Bourdieu's book The State Nobility is "doggedly francocentric in empirical substance and style, yet irrepressibly universalizing in analytical intent and reach" (Wacquant 1996:ix) may be easily extrapolated to much of Bourdieu's 
work. This work is then shown, on the one hand, to be somewhat of a paradox - a paradox no doubt related to Bourdieu's incessant calls for reflexivity and a critical reflection on sociology's own modus operandi (cf. Bourdieu 1982; Bourdieu and Wacquant 1992; Bourdieu 2001b). The paradox lies in the critique of universalizing a particular on the basis of a universalizing analysis of a particular.

On the other hand, Bourdieu's work then appears as constrained by the limits of its main site of analysis: France. Since this is, as noted, a context where the notion of profession never has had much currency, it is doubtful whether Bourdieu exhausted - to use his own terms (cf. Bourdieu 2001:54) - the possibilities of his own modus operandi in his opus operatum. Although, on the one hand, the scientific community is increasingly part of a transnational field that undermines various forms of national "sens commun" (Bourdieu 1997a:119), Bourdieu is inclined to critique the Americanization of social science (Bourdieu and Wacquant 1999:46-48) as he does in case of the economy (Bourdieu 2000b:23). "Americanization" here is a shorthand for a dismissive grand gesture.

These are some limitations to Bourdieu's critique. More fundamentally, however, is the selectivity with which he chooses to discard or take on board concepts. His critique of the concept of professionalism appears somewhat selective precisely in light of the biased nature of his critique of Americanization. Language is a site of symbolic power (Bourdieu 2001: 201ff.). But that goes for many concepts that Bourdieu nonetheless takes on board. In fact, in his discussion of various societal fields, he is happy to make use of occupational denominations, while recognizing the struggles for the legitimate definitions of the content of such denominations.

Thus, in his work on science, the concept of scientist is not subject to similar critical scrutiny as is the concept of profession. The same goes for a concept such as artist. While extremely critical of the "charismatic ideology" in the field of cultural production, an illusio involving the idea of the artist as sole creator of the work of art (Bourdieu 1993:75-76), Bourdieu never chooses to dismiss the concept of artist. And this is, we believe, with good reason, for the concept is socially productive. It can be used in sociological analysis of the field of cultural production under the condition that it is not taken at face value, but rather as a concept that masks a struggle over the legitimate definition of the referent of that very concept. 
What is more, in The State Nobility, Bourdieu himself makes use of the concepts of "professions" and "professionals" without the radical critique he later explicated (Bourdieu 1996b:336). Such arguments, combined with the limitations to Bourdieu's critique, merit a more nuanced sociological treatment of the concept of profession, notwithstanding the fundamental critique inherent in Bourdieu's methodological underpinnings. So the question is how to conceptualize notions such as "profession", "professionalism" and "professionalization" in a critical and reflexive sociological framework?

\section{Professionalism as Symbolic Capital}

Put in other words, the question is: What difference does "professionalism" make? Available constructionist and often critical interpretations of professionalism offer some first arguments for a conceptualization of professionalism as symbolic capital. Professionalism can be seen as a social construction that acquires (new) forms and shapes in changing economies and labour organizations, in a changing "occupational world" (cf. Evetts 2003), with changing "work places" and career patterns (Leicht and Fennell 2001), and trans-national professional linkages and networks (e.g. Greenwood et al. 2002).

Powell and DiMaggio (1983) see the spread of professionalism as "institutional isomorphism," that is, as a matter of imitating others and moving towards similar practices and structures in order to seek legitimacy and construe forms of "collective rationality." Watson (2002) sees professionalism as a "discursive resource" which is used to cope with ambiguous circumstances and to serve sectional interests (see also Hodgson 2004). Fournier (1999) also explains the "appeal to professionalism" by exploring "the discursive resources of professionalism in new occupational domains" that "potentially act as disciplinary mechanism that serves to profess appropriate work identities and conducts." Hodgson (2002, 2005) sees professionalism as a means to "put up a professional performance" in order to discipline ambiguous work. Hodgson and Cicmil (2007) see professionalism as "projects" of standardization, aimed at "naturalizing" organizational objects.

These views offer interesting ways to define professionalism in light of the impossibility of defining it in crisp, clear ways. Perhaps we should 
treat professionalism as a dynamic concept, as a verb in stead of a noun "professionalization" - and not as a static concept with generic, fixed and universal features. Although the notion will unavoidably be related to knowledge, expertise, associations, closure, status, schooling, standards and codes, and will serve distinctive organizational, social and ideological objectives, changing societies will experience the continuous manufacturing of professionalism. That is, they will experience processes in which ideals of professionalism are (re)constructed. In these processes, the notion of professionalism becomes an explicit discursive resource, symbols are invoked in order to legitimate ambiguous work, and standards are initiated in order to coordinate and discipline workers.

Bourdieu's notion of field imbues his analysis with a crucial historical dimension. Rather than seeing a field as a static given, as a structure in structuralism for instance, Bourdieu focuses on the historical genesis and autonomization of social fields. In An Invitation to Reflexive Sociology he describes a field as containing many aspects amenable to study in light of processes of professionalization:

A field may be defined as a network, or a configuration, of objective relations between positions. These positions are objectively defined, in their existence and in the determinations they impose upon their occupants, agents or institutions, by their present and potential situation (situs) in the structure of the distribution of species of power (or capital) whose possession commands access to the specific profits that are at stake in the field, as well as by their objective relation to other positions (domination, subordination, homology, etc.). (Bourdieu 1992:97)

Moreover, for Bourdieu, the historical genesis of contemporary social struggles is crucial. As he says, "there is a field effect when one can no longer understand a work (and the value, that is to say the belief, which is accorded to it) without knowing the history of the field of production of that work" (Bourdieu 1984b:117).

Bourdieu's approach is thus able to add to the existing sociology of occupations:

- a focus on the historical genesis of power-driven autonomous fields;

- an emphasis on the symbolic capital at stake in professional fields;

- a recognition of the dynamic nature and vulnerability of professional fields; 
- the importance of habitus/field coordinations and the associated forms of dominance, submission and logics of hierarchization; and

- the recognition of the scarcity of recognition, that is, of the scarcity of symbolic capital in professional fields.

We therefore propose to see "professionalism" as a form of symbolic capital characteristic of a historically constructed field of power. This can be linked to available constructionist and critical accounts of professionalism, but it also adds a lot.

The construction of professionalization "projects" and the struggles over (discursive) resources take place within more historical and structural contexts. These contexts determine whether specific field can arise in which "professionalism" can function as symbolic capital. In short, when we take available conceptions of professionalism and connect them to Bourdieusian thinking, professionalism can be seen as symbolically controlled content in autonomous but dynamic contexts of struggle. Both content and context can be elaborated in order to understand professionalismas-construction.

The content of professionalism is constantly at stake and can be characterized as controlled content (Noordegraaf 2007). The traditional notion of professionalism involves all the well-known more or less functionalist aspects of autonomy: a service ethic, some form of association, and a secure technical knowledge base. This can be cast into an ideal-type in which workers control their own work (cf. Freidson 2001). It is present in Abbott's notion of "professionalism" as "exclusive occupational groups applying somewhat abstract knowledge to concrete cases" (Abbott 1988:8). But such definitions and "ideal-types" are in need of historical study, such as that performed by Larson in her book The Rise of Professionalism (1977).

This sort of analysis fits well with Bourdieu's work to the extent that it allows for a critical take on the autonomization of professions. But in Larson these professions are nonetheless treated as givens, albeit as historically constituted givens. Professionalism as symbolic capital entails the idea that professionalism is constantly at stake, that the content of professionalism is continuously contested within the limits of a context which, in turn, it is a defining characteristic. From our Bourdieusian perspective, the rise of the professional would be interpreted as a way of gaining social 
status next to nobility and bourgeoisie. Where the remnants of nobility possessed social capital as symbolic capital, and where the upcoming bourgeoisie possessed economic capital, professionalism was a third way, a form of status or symbolic capital based on cultural capital.

\section{Professional Fields in the Field of Power}

Professionalism as symbolic capital allows for a securing of autonomy visà-vis other social fields. It is the successful claim to professionalism that ensures social closure of a field. The notion can therefore help explain how and why social fields are able, as Bourdieu argues, to autonomize.

But in a Bourdieusian perspective, the question needs to be: which field is at stake here? A first answer concerns the "internal" role of professionalism and the internal struggles for dominant positions within specific occupational fields. But alongside such "internal" struggles, an "external" struggle exists between professions and professionalizing occupations, as well as between professions and fields exerting deprofessionalizing forces.

So a second answer lies in what Bourdieu more generally calls the "field of power." Next to the social space of the classes, and next to various "topical" social fields, such as science, politics, the economy, and others, Bourdieu discusses what he calls "the field of power" (le champ du pouvoir) which he warns should not be mistaken for the field of politics (Bourdieu 1994:56). This concept is somewhat misleading, since any field obviously is a field of power. What Bourdieu intends to capture by this notion is a field of struggle not reducible to the social space of the classes nor to any of the autonomous societal fields that are reminiscent of what Weber called "value spheres" or Luhmann called "functional subsystems" (Luhmann 1997).

The field of power comprises, as Loïc Wacquant states, "the chain of interdependencies that sews [the multiplicity of fields] together" (Wacquant 1996:xi). It is this more general field of power in which Bourdieu, for instance in The State Nobility (1996b:261ff.), situates various economic and cultural fields and their respective struggles for relative social status.

One might say that a phenomenological embodiment of illusio is "the precondition for successful entry into the field" (Bourdieu 1996b:170). A professional habitus thus consists of predispositions that simultaneously reproduce and manipulate the borders of an occupation both within a 
specific professional field and within the larger field of power in which such a professional field is situated. Professionalism, moreover, is a scarce resource. For professionalism to function as symbolic capital, its access needs to be restricted on the basis of a submission of occupational fields lacking the symbolic status of "profession." This submission itself is based on the shared recognition of the legitimacy of professionalism as symbolic capital. In that sense, the realization of the sociological vision, critiqued by Wilensky (1964), of a "professionalization of every one" would mean the end of the symbolic value of professionalism.

In competing for symbolic status with other occupations, a profession is structured as one subfield of the field of power able to claim such status in the form of professional capital recognized as such by others in the field of power, including occupations unsuccessfully claiming such recognition. That is why the traditional professions are still most readily visible as such. They at the same time occupy positions in those fields in society that rose to prominence during the nineteenth century's increasing differentiation, what for Durkheim (1984) was the "division of labour."

Bourdieu's field analysis is often used and interpreted "internalistically." In such an analysis, one would point out that the field-specific content of "professionalism" or the very reference of the idea of a specific "profession" is continuously at stake within a specific professional field. But the idea of a "profession" marks not only a field in itself but at the same time a difference within a larger relational system of positions. Bourdieu's notion of the field of power enables us to see professions as fields of positions nested within a general field of power.

Within such an analysis one would highlight the struggles over the formal content of "professionalism" across all professional fields and vis-à-vis other occupations. This resembles very much what Abbott has provided in The System of Professions. Yet the advantage of Bourdieu's perspective lies not only in its critical perspective, that is, in its "second order" view of the very concept of profession, but also in its general theoretical vocabulary, which allows for comparisons not only across professions but also across professional fields and other fields.

Professional fields can thus be in competition with non-professional fields, and such conflicts may derive from the fact that what is symbolic capital for one field is simply another form of cultural, social or economic capital for another. In the perspective we propose, professions are then 
networks of positions that successfully claim professional capital and that, in doing so, are able to dominate over occupations unsuccessful in doing so. A profession forms "a system of objective relations between [...] agents or institutions and [...] the site of the struggles for the monopoly of the power to consecrate" (Bourdieu 1993:78). ${ }^{2}$ The success of claiming professional capital is the outcome of a historical process that can be analyzed in analogy to Larson (1977) and would focus both on the genesis of a field of positions and on the shaping of systems of dispositions (babitus).

With respect to available constructivist approaches it should be emphasized that a Bourdieusian approach would stress distinction as much as imitation, and moreover would expand the concept beyond mere "discursive resources" toward an embodied practical sense (Bourdieu 1990b). What is at stake is the ability to give symbolic weight to certain educational resources, to codes of conduct and to institutional guarantees of occupational exclusivity, that is, the ability to make a difference.

As Abbott notes, many occupations entail licensure or ethics codes (Abbott 1988:9), but this doesn't mean such occupations are professions. While Abbott claims it is a "knowledge system governed by abstractions" that secures the use of the concept, we would argue it is only the successful struggle for dominance in the field of power, together with the successful claim to professional capital that does so. In many cases, this involves the transformation of cultural capital (such as knowledge systems governed by abstractions) into symbolic capital, on the basis of corresponding embodied dispositions giving rise to actions and interpretations that bear the mark of "professionalism."

One example is the medical profession, which was able to gain autonomy on the basis of a scientific method that set it apart from earlier medical knowledges. It was able to set up requirements for entry through education that transmitted the professions' cultural capital, its medical expertise, and that hence contributed to the (re)production of such cultural capital as symbolic capital. This gave rise to professionals imbued with a medical habitus, able to recognize situations relevant to their profession and to act "naturally" yet based on professional dispositions gained during their training.

2) Bourdieu is here referring to the field of cultural production. 
This at the same time involves the distinction and hence the distancing of those imbued with a professional habitus from those who are not (compare Johnson 1972:41). The relationships with the latter are characterized by a distance on the basis of a socially constructed difference deemed legitimate by those who lack specific professional acclaim. And it can be coded either as relationships between professional and client, between professional and semi- or non-professional, between professional and bureaucrat or between professional and manager. These struggles are struggles over capital, in terms of both appropriation as well as exploitation. They are played out in order to construct new fields that previously were not considered "professional," and this "widening" of professionalism negatively affects the scarcity of professional capital and raises fundamental questions concerning the future of professional work. For professional capital, like any other form of symbolic capital, is necessarily a scarce resource. Were it not for this scarcity of professional capital, it would be impossible to claim professional status and thereby indeed gain status. Professional autonomy in a sense consists of the regulation of such scarcity.

\section{Discussion: Professionalism at Stake}

Conceptualizing professionalism as symbolic capital means professions are occupational networks nested in what Bourdieu terms the field of power. "Professionalization" is then a process of struggle over the attainment of professionalism as symbolic capital. Such struggles are always also struggles over legitimate definitions of professionalism.

We discuss a few general forms in which such struggles become manifest, affecting classic professions as well as modern and new professions. This discussion is limited; it is expanded and refined in the next paper, with particular emphasis on clashes between professionalism and managerialism, and the rise of professional managers.

First of all, changes in the nature of work, such as automatization, the introduction of "evidence-based" routines, amount to de-professionalization of classic professions. Second, changes in the nature of firms, such as increased internal competitiveness, accountability and risk control, and performance measurements amount to corporatization of professional work. Third, changes in organizational mechanisms, such as neoliberal 
forms of management, amount to managerial control of professional behaviour. These processes function as restructuring pressures in the field of power in which the professions are nested. As indicated, they tend to affect the availability and accessibility of professional capital and tend to lower its value.

\section{Powerful Pressures}

Instead of seeing professionalism as a matter of class-based social grouping, authors like Steven Brint (1994) have stressed the time-bound nature of professional work. Whereas professionalism used to be a matter of what he calls "social trustee" professionalism - professionals as esoteric workers, embodying vocational and societal callings - it has turned into what he sees as expert professionalism. It is now a way of organizing work in complex expert economies. Others emphasize the rise of critical clients or outspoken consumers and consumerism, seeing these factors undermining the autonomy and authority of professionals. Professionals will have to open-up and account for their actions first of all within their own organizational hierarchies. Both expert professionalism and the rise of consumerism tend to de-professionalize certain practices (e.g. Freidson 1984; Broadbent et al. 1997).

In addition, (classic) professionals like medical doctors and lawyers have become part of corporate structures that have been developed to cope with global competitive pressures. Hospitals have become more competitive institutions, and competition on global markets tends to add pressure to existing professional fields, while these fields often remain heavily structured on nationalist bases, for instance where expertise systems are concerned. Professionals have become part of "restructured professional organizations," that is, "professional service firms" or "managed professional businesses" (e.g. Brock et al. 1999; Powell et al. 2002). In other words, professionalism is no longer seen as a strong shelter, relatively unaffected by market logics, merit and performance. The balance has instead shifted towards a situation in which professional fields are more often subject to capitalistic control. The professional is "threatened" by all such developments and there is talk of his or her possible "proletarianization," which would reduce the status of professional to that of any other worker. If that were to be the case, the "historical project" of profes- 
sionalism, which was a way to gain status next to nobility and capitalist bourgeoisie, a status based on cultural capital and not on social capital (nobility) or economic capital (bourgeoisie) will have failed.

Finally, within service firms or professional businesses (see Brock et al. 1999:222) professionalism is at stake in struggles over control, most prominently in struggles between professionals and managers. Managers install disciplinary techniques such as work routines and evaluation mechanisms in order to control professional behaviours, and professionals appear to be "persecuted professionals" (Farrell and Morris 2003).

Yet from a Bourdieusian perspective such "persecution" is to be seen as a permanent state, or perhaps as a successful challenge to received legitimate notions of professionalism. This becomes apparent in managers' desire to emulate professional organization. Paradoxically, the professionalization of the manager is itself part of the pressure on the symbolic capital of professionalism, not only because professionals experience pressure from managers, but also because it constitutes a further expanding of the use of and claim to professional capital. The very professionalization of managers thereby tends to be somewhat self-refuting. Yet professional status in a very old-fashioned sense is clearly what managers appear to aspire.

Managers increasingly organize in associations with codes of conduct. They try to secure collective closure through education in the form of business schools granting legitimate certificates of "professional managerialism." For many, the professional manager is no longer a contradiction in terms. While Bourdieu might have taken a normative stance here, we argue that this issue can only be decided empirically. If managers succeed in claiming professional legitimacy, then form our sociological perspective, it is warranted to say that managers occupy positions within a specific professional field that is nested within the larger field of power.

Traditional professionals, on the other hand, resist such developments, and an oft-heard argument is that the "professional manager" is in fact a contradiction in terms, plausible only on the basis of an "ideology" of managerialism (Pollitt 1993, Ackroyd et al 2007; for more elaboration, see the next article). Such debates on professionalism and managerialism in a sense restate debates on professionalism and bureaucracy taking place during the 1950s and 1960s. In this debate compromises, or even hybrid forms, were found to exist, for instance in the form of a "professional 
bureaucracy" (cf. Litwak 1961, Smigel 1964). According to Litwak (1961), contemporary society is characterized most of all by complex organizations of this type (alongside "Weberian" or hierarchical and "human relations" or interpersonal types of organizations).

In a similar fashion, Peter Blau saw a mutual dependence and convergence between professionalism and centralized bureaucracy (Blau 1955). Others showed how professionalization increased within bureaucratized networks, and how this took place (in general high schools) through a form of "militant professionalism" (Corwin 1970). By this Corwin meant the shaping of professionalism through conflicts induced by the structure of schools.

In current debates managerialism is associated more with economic capital while traditional professionalism is associated more with cultural capital (see the next article). But when managers seek symbolic capital, they revert to institutionalizing forms of cultural capital. Business schools are an example par excellence of converting economic capital into cultural capital: by using economic capital to set up educational institutions, a way is gained to generate cultural capital (diplomas and certificates). The "tragedy" of this is that it leads to a possible devaluation of this symbolic capital, since, as explained above, it is crucial for the symbolic value of professional capital that conditions of relative scarcity are maintained.

\section{Conclusion}

Bourdieu's critique of the concept of "profession" is potent but it is at the same time too one-sided. It is possible to analyze in a Bourdieusian fashion processes of professionalization within autonomous professional fields and across a larger social field of power. If professionalism is regarded as a form of symbolic capital this is constantly at stake with respect to its content. One thereby gains the possibility of analyzing it with respect to its role in power-driven contexts both internally and externally.

Professional fields are embedded in objective relations with other fields in a general field of power. Within each professional field, the legitimate substance of what it means to act in a "professional way" is constantly at stake. And across various professional fields, within what Bourdieu describes as a larger field of power, the very idea or "formal content" of "professionalism" is subject to struggle and (re)negotiation. Existing 
approaches to professional occupations have the advantage of specifying both work content and work context, as well as the construction of autonomy in webs of dependency.

We have argued that it is possible to combine the fruitfulness of existing approaches with the reflexive approach Bourdieu offers. A Bourdieusian approach adds not only a power-centered view of professionalism as a scarce symbolic resource, which is the object of a work of consecration and the source of legitimate forms of acting and interpreting. It also brings a critical and reflexive dimension into the sociology of the professions. Such an analysis de-essentializes talk of the professions and of professionalization. It recognizes the constructed nature of such professions, that is, the misrecognized arbitrary nature of professional discursive resources and of legitimate professional modes of acting and interpreting. In other words, it recognizes the work of recognition of professional work as a form of symbolic capital that is possible only on the basis of a continuous misrecognition.

\section{References}

Abbott, Andrew. 1988. The System of Professions. An Essay on the Division of Expert Labor. Chicago: The University of Chicago Press.

Barber, Bernard. 1963. "Some Problems in the Sociology of Professions." Daedalus 92(4):669-688.

Bell, Daniel. 1973. The Coming of Post-Industrial Society. New York: Basic Books.

Blau, Peter Michael. 1955. The Dynamics of Bureaucracy. Chicago: University of Chicago Press.

Bourdieu, Pierre. 1977. Outline of a Theory of Practice. Cambridge: Cambridge University Press.

- 1982. Leçon sur la leçon. Paris: Minuit.

-1984a. Homo academicus. Paris: Minuit.

- 1984b. Questions de sociologie. Paris: Minuit.

- 1986. "Forms of Capital." in Handbook of Theory and Research for the Sociology of Education, edited by John G. Richardson. New York: Greenwood.

- 1990a. The Logic of Practice. Cambridge: Polity Press.

- 1990b. "The Scholastic Point of View." Cultural Anthropology 5:380-391.

- 1993. The Field of Cultural Production. Cambridge: Polity.

—. 1994. Raisons pratiques. Sur la théorie de l'action. Paris: Seuil.

- 1996a. Distinction; a Social Critique of the Judgement of Taste. Cambridge: Harvard University Press.

- 1996b. The State Nobility. Elite Schools in the Field of Power. Cambridge: Polity. 
—. 1997a. Méditations pascaliennes. Paris: Seuil.

1997b. Les usages sociaux de la science. Pour une sociologie clinique du champ scientifique. Paris: INRA.

— 1998a. Acts of Resistance: Against the New Myths of our Time. Cambridge: Polity. 1998b. On Television. London: Pluto Press.

1999. The Weight of the World. Social Suffering in Contemporary Society. Cambridge: Polity Press.

—. 2000a. Propos sur le champ politique. Lyon: Presses Universitaires de France.

—. 2000b. Les structures sociales de l'économie. Paris: Seuil.

- 2001. Langage et pouvoir symbolique. Paris: Seuil.

Bourdieu, Pierre and Loïc Wacquant. 1992. An Invitation to Reflexive Sociology. Cambridge: Polity.

—. 1999. "On the Cunning of Imperialist Reason.” Theory, Culture \& Society 16(1):41-58.

Brint, Steven. 1994. In an Age of Experts: The Changing Role of Professionals in Politics and Public Life. Princeton, NJ: Princeton University Press.

Broadbent, Jane, Michael Dietrich and Jennifer Roberts. 1997. The End of the Professions. New York: Routledge.

Brock, David, Michael J. Powell and Christopher Robin Hinings, eds. 1999. Restructuring the Professional Organization. London: Routledge.

Bucher, Rue and Anselm Straus. 1961. "Professions in Process." American Journal of Sociology 66(4):325-334.

Carr-Saunders and Alexander Morris. 1928. Professions: Their Organization and Place in Society. Oxford: The Clarendon Press.

Carr-Saunders, Alexander Morris and Paul Alexander Wilson. 1933. The Professions. London \& Oxford: Oxford University Press.

Collins, Randall. 1979. The Credential Society. New York: Academic Press.

Corwin, Ronald G. 1970. Militant Professionalism. A Study of Organizational Conflict in High Schools. New York: Appleton-Century-Crofts.

DiMaggio, Paul J. and Walter W. Powell. 1983. "The Iron Cage Revisited: Institutional Isomorphism and Collective Rationality in Organizational Fields." American Sociological Review 48(2):147-160.

Durkheim, Emile. 1915. The Elementary Forms of Religious Life. London: George Allen \& Unwin.

- 1984. The Division of Labor in Society. New York: The Free Press.

Etzioni, Amitai. 1969. The Semi-Professions and their Organisation: Teachers, Nurses, and Social Workers. New York: The Free Press.

Evetts, Julia. 2003. "The Sociological Analysis of Professionalism.” International Sociology 18(2):395-415.

Farrell, Catherine and Jonathan Morris. 2003. "The 'Neo-Bureaucratic' State: Professionals, Managers and Professional Managers in Schools, General Practices and Social Work." Organization 10(1):129-156.

Faunce, William A. and Donald A. Clelland. 1967. "Professionalization and Stratification Patterns in an Industrial Community." American Journal of Sociology 72(4):341-350. 
Fournier, Valérie. 1999. "The Appeal to Professionalism as a Disciplinary Mechanism.” The Sociological Review 47(2):280-307.

Freidson, Eliot. 1984. "The Changing Nature of Professional Control." Annual Review of Sociology 10:1-20.

- 1986. Professional Powers: A Study of the Institutionalization of Formal Knowledge. Chicago: Chicago University Press.

- 1994. Professionalism Reborn. Cambridge: Polity.

- 2001. Professionalism: The Third Logic. Cambridge: Polity Press.

Greenwood, Royston, Roy Suddaby and Christopher Robin Hinings. 2002. "Theorizing Change: The Role of Professional Associations in the Transformation of Institutionalized Fields." Academy of Management Journal 45(1):58-80.

Hodgson, Damian. 2002. "Disciplining the Professional: The Case of Project Management." Journal of Management Studies 39(6):803-821.

- 2004. "Project Work: The Legacy of Bureaucratic Control in the Post-Bureaucratic Organization." Organization 11(1):81-100.

—. 2005. "Putting on a Professional Performance: Performativity, Subversion and Project Management." Organization 12(1):51-68.

Hodgson, Damian and Svetlana Cicmil. 2007. "The Politics of Standards in Modern Management: Making the Project a Reality." Journal of Management Studies 44(3):431-450. Johnson, Terence J. 1972. Professions and Power. London: Macmillan.

Krause, Elliott A. 1996. Death of the Guilds. New Haven: Yale University Press.

Larson, Magali Sarfatti. 1977. The Rise of Professionalism: A Sociological Analysis. London: University of California Press.

Latour, Bruno. 1996. Aramis, or the Love of Technology. Cambridge: Harvard University Press.

Leicht, Kevin T. and Mary L. Fennell. 1997. "The Changing Organizational Context of Professional Work.” Annual Review of Sociology, 23:215-31.

—. 2001. Professional Work: A Sociological Approach. Malden, MA: Blackwell Publishers.

Lévi-Strauss, Claude. 1963. Structural Anthropology. Harmondsworth: Penguin.

Lewis, Roy and Angus Maude. 1952. Professional People. London: Phoenix House.

Litwak, Eugene. 1961. "Models of Bureaucracy Which Permit Conflict." American Journal of Sociology 67(2):177-184.

Luhmann, Niklas. 1997. Die Gesellschaft der Gesellschaft. Frankfurt/M.: Suhrkamp.

Macdonald, Keith M. 1995. The Sociology of the Professions. London: Sage.

Noordegraaf, Mirko. 2006. "Professional Management of Professionals: Hybrid Organisations and Professional Management in Care and Welfare." In Policy, People, and the New Professional, J. W. Duyvendak, T. Knijn and M. Kremer (red.). Amsterdam: Amsterdam University Press.

—. 2007. "From Pure to Hybrid Professionalism. Present-day Professionalism in Ambiguous Public Domains.” Administration \& Society 39(6):761-785.

Parsons, Talcott. 1939. "The Professions and Social Structure." Social Forces 17(4):457-467.

— 1954. Essays in Sociological Theory. New York: Free Press. 
Powell, Michael J., David Brock and Christopher Robin Hinings. 2002. "The Changing Professional Organization.” in Restructuring the Professional Organization, D.M. Brock, M.J. Powell and C.R. Hinings. New York: Routledge.

Robbins, Derek. 2000. Bourdieu \& Culture. London: Sage.

Robertson, Roland. 1995. Glocalization: Time-Space and Homogeneity-Heterogeneity, in Global Modernities, edited by M. Featherstone, S. Lash and R. Robertson. London: Sage.

Saussure, Ferdinand De. (1916) 1983. Course in General Linguistics. London: Duckworth. Schinkel, Willem. 2003. "Pierre Bourdieu's Political Turn?" Theory, Culture \& Society 20(6):69-93.

—. 2007. "Sociological Discourse of the Relational: The Cases of Bourdieu and Latour." The Sociological Review 55:707-729.

Schinkel, Willem and Jacques Tacq. 2004. "The Saussurean Influence in Bourdieu's Relational Sociology." International Sociology 19(1):51-70.

Schön, Donald A. 1983. The Reflective Practitioner. New York: Basic Books.

Sciulli, David and Jeffrey A. Halley. 2009. "Professions and Burgertum: Etymological Ships Passing, Night into Day.” Comparative Sociology 8:202-246.

Smigel, Erwin Orson. 1964. The Wall Street Lawyer: Professional Organization Man? New York: The Free Press.

Smith, Anthony D. 1983. "Nationalism and Classical Social Theory." British Journal of Sociology 34(1):19-38.

Torstendahl, Rolf and Michael Burrage, eds. 1990. The Formation of Professions. Knowledge, State and Strategy. London: Sage.

Vandenberghe, Frederic. 1999. "'The Real is Relational': An Epistemological Analysis of Pierre Bourdieu's Generativ Structuralism.” Sociological Theory 17(1):32-67.

Vollmer, Howard M. and Donald L. Mills. 1965. "Some Comments on 'The Professionalization of Everyone?” American Journal of Sociology 70(4):480-481.

Vollmer, Howard, M. and Donald L. Mills, eds. 1966. Professionalization. New Jersey, Prentice Hall.

Wacquant, Loïc. 1996. "Foreword." Pp. ix-xxii in Bourdieu, P., The State Nobility. Elite Schools in the Field of Power. Cambridge: Polity.

Watson, Tony. 2002. "Professions and Professionalism: Should We Jump Off the Bandwagon, Better to Understand Where It Is Going?" International Studies of Management and Organization, 32(2):94-106.

Wilensky, Harold L. 1964. "The Professionalization of Everyone?" American Journal of Sociology 70(2):137-158. 